\title{
Linkage analysis of polymorphisms within the DNA fragment XJ cloned from the breakpoint of an X;21 translocation associated with $\mathrm{X}$ linked muscular dystrophy
}

\author{
MARGARET W THOMPSON, PETER N RAY, BONNIE BELFALL, \\ CATHERINE DUFF, CAIRINE LOGAN, IRINA OSS, AND \\ RONALD G WORTON
}

From the Department of Genetics and Research Institute, The Hospital for Sick Children, Toronto, Ontario M5G 1X8; and the Department of Medical Genetics, University of Toronto, Toronto, Ontario M5S 1A1, Canada.

SUMmARY Cloning of a DNA segment including the translocation breakpoint in a female with an $\mathrm{X} ; 21$ translocation and $\mathrm{X}$ linked muscular dystrophy has led to identification of three subclones which detect polymorphic markers. The alleles of these markers, $\mathrm{XJ} 1 \cdot 1, \mathrm{XJ} 1 \cdot 2$, and XJ2 2 , are in strong linkage disequilibrium. Linkage analysis in 31 families with Duchenne or Becker muscular dystrophy has shown recombination within the $\mathrm{XJ}$ segment in one case, and recombination of DMD with both the XJ segment and the pERT87 segment in a second, but has revealed no recombination between the XJ and pERT87 segments. The XJ markers increase the proportion of DMD and BMD families that are informative for carrier detection and prenatal diagnosis, but in view of the risk of recombination they must be used with caution. The site(s) of the DMD mutation(s) relative to the XJ and pERT87 markers, and the detailed molecular structure of the DMD region, remain to be determined.

The locus for Duchenne muscular dystrophy (DMD) has been mapped to the short arm of the $\mathrm{X}$ chromosome at band Xp21, by family studies and by analysis of structural abnormalities of the $X$ chromosome. ${ }^{1-10}$ The locus for Becker muscular dystrophy (BMD), a disorder overlapping DMD phenotypically and distinguished from DMD arbitrarily on the basis of its milder clinical course, has also been mapped to $\mathrm{Xp} 21,{ }^{11-13}$ but there is still uncertainty as to whether the mutations responsible for DMD and BMD are allelic or occur within closely linked loci.

A number of translocations that have been ascertained in females with DMD or BMD are of particular interest, as they have all involved a breakpoint in $\mathrm{Xp} 21$ and reciprocal translocation with an autosome. Disruption of the Xp21 muscular dystrophy locus by the translocation, coupled with non-random inactivation of the other (normal) $\mathrm{X}$ chromosome, seems to be responsible for the

Received for publication 28 July 1986.

Accepted for publication 4 August 1986 disease in these girls. Although all the known translocation exchange points are in band Xp21, high resolution cytogenetic analysis of several cases has suggested heterogeneity of the exchange points within this rather large band. ${ }^{14}$

One of the translocation females is a Belgian woman with a form of muscular dystrophy originally diagnosed as DMD, who was found to have an $\mathrm{X}$; autosome translocation, $\mathrm{t}(\mathrm{X} ; 21)(\mathrm{p} 21 ; \mathrm{p} 12)$, with one exchange point near the Duchenne locus in $\mathrm{Xp} 21$ and the other within a cluster of ribosomal RNA genes at $21 \mathrm{p} 12 .{ }^{415}$ Sequences from the ribosomal RNA genes have been used as probes to clone a DNA segment spanning the translocation breakpoint. ${ }^{16}$ Within the $\mathrm{X}$ chromosomal portion of the initial clone $\mathrm{XJ} 1$, two subclones, $\mathrm{XJ} 1 \cdot 1$ and $\mathrm{XJ} 1 \cdot 2$, from the centromeric side of the junction have been found to detect restriction fragment length polymorphisms (RFLPs). By 'chromosome walking' along a normal $\mathrm{X}$ chromosome, an adjacent segment from the telomeric side of the translocation has also been cloned, and a third RFLP has 
been identified with subclone $\mathrm{XJ} 2 \cdot 2$ of that segment. In this report we describe the linkage relationships of these three RFLPs to one another, to DMD (or $\mathrm{BMD}$ ), and to several other Xp markers within close linkage distance of the $\mathrm{Xp} 21$ muscular dystrophy gene, which we will refer to as DMD.

\section{Materials and methods}

CHROMOSOME WALKING AND RFLP ANALYSIS Bacteriophage clones overlapping $\mathrm{XJ} 1$ were isolated from a human DNA recombinant library constructed in $\lambda$ charon $35^{17}$ from size selected (13 to 20 $\mathrm{kb}$ ) partially Sau3A digested DNA derived from a female XXXX cell line (GM1202, Camden Repository). The unique sequence probes $\mathrm{XJ} 1 \cdot 1$ and $\mathrm{XJ} 1 \cdot 2$ from the junction clone $\mathrm{XJ} 1^{16}$ were used to screen nitrocellulose lifts from primary plates of the library by standard technology, ${ }^{18}$ and hybridising phage were plaque purified through three rounds of selection. All clones were restriction mapped with $B a m H I, E c o$ RI, $X b a I$, and HindIII, and the clones containing sequences extending the farthest in the telomeric and centromeric directions were designated $\mathrm{XJ} 2$ and $\mathrm{XJ} 3$ respectively. Fragments from these walk clones were subcloned into either pUC $19^{19}$ or pSP65. ${ }^{20}$

In order to screen for RFLPs, DNA from six unrelated persons (five females, one male) was digested with each of 27 restriction enzymes, separated by electrophoresis in agarose gels, and transferred to nitrocellulose or other suitable substrate. The blots were probed with unique sequence fragments from the bacteriophage subclones, ${ }^{32} \mathrm{P}$ radiolabelled by nick translation. Three probes, designated $\mathrm{XJ} 1 \cdot 1, \mathrm{XJ} 1 \cdot 2$, and $\mathrm{XJ} 2 \cdot 2$, showed RFLPs with enzymes $T a q \mathrm{I}, B c I \mathrm{I}$, and $T a q \mathrm{I}$, respectively. The spatial arrangement of these probes within the $\mathrm{XJ}$ segment is indicated schematically in fig 1 .

\section{FAMILY MATERIAL}

The probands of the 31 families described in this report have been diagnosed and followed through the Muscular Dystrophy Clinic of the Hospital for Sick Children. Only one family has classical BMD; in three other families the precise clinical classification of the disorder as DMD or BMD remains uncertain, and in the remainder the patients have classical DMD. For the present study, the different clinical types have not been analysed separately.

Linkage analysis involving DMD has been restricted to the offspring of women who are obligate heterozygotes. Among these offspring, affected males, normal males, and obligate heterozygotes have been classified as category $\mathrm{A}$; presumed heterozygotes who are first degree relatives of affected males or obligate heterozygotes and have grossly raised serum creatine kinase (CK) activity have been classified as category $\mathrm{B}$; and females of uncertain DMD genotype (that is, with $\mathrm{CK}$ in the normal range or not grossly raised) are classified as category C. For this classification we define 'grossly raised' CK activity as $20 \%$ above the $95 \%$ limit of the normal range for age and sex in three separate assays at least two weeks apart. Data for linkages involving DMD are presented separately for categories $\mathrm{A}$ and $\mathrm{B}$; for linkages not involving DMD, data for category $\mathrm{C}$ females are also included and the three categories are pooled.

The families were typed for the XJ polymorphisms and for some or all of the following (listed in sequence from distal to proximal on Xp): pXUT23,

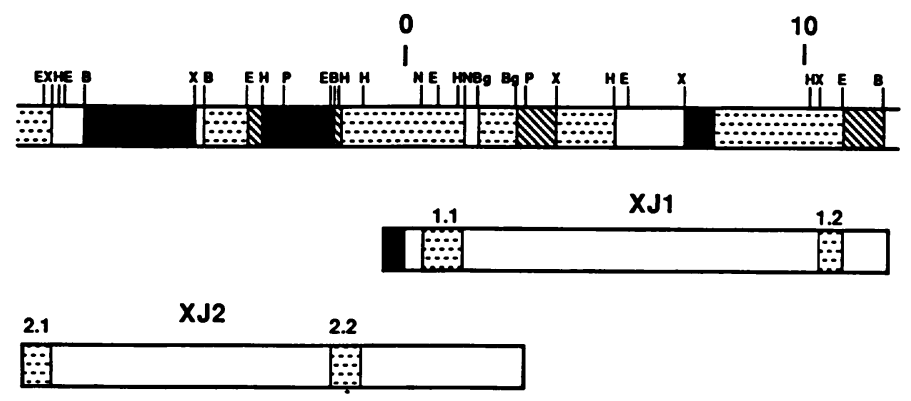

FIG 1 Schematic map of the genomic region surrounding the $X ; 21$ translocation breakpoint. DNA segments free of human repeated sequences are represented as stippled blocks, those with moderate repeats are cross hatched, and those with highly repeated sequences are solid black. White blocks show areas that have not been tested. Restriction sites for BamHI (B), $\operatorname{EcoRI}(E), \operatorname{HindIII}(H), \mathrm{XbaI}(X), \mathrm{NsiI}(N), B g I I(B g)$, and PstI $(P)$ are indicated above the map. The position of the X;2I translocation breakpoint is at $0 \mathrm{~kb}$. The $\lambda$ phage clones $X J 1$ and $X J 2$ are represented below the map; the relative positions of polymorphic probes $X J 1 \cdot 1, X J 1 \cdot 2$, and $X J 2 \cdot 2$ are indicated. 
TABLE 1 Summary of previously published polymorphic markers on Xp analysed for linkage in this report

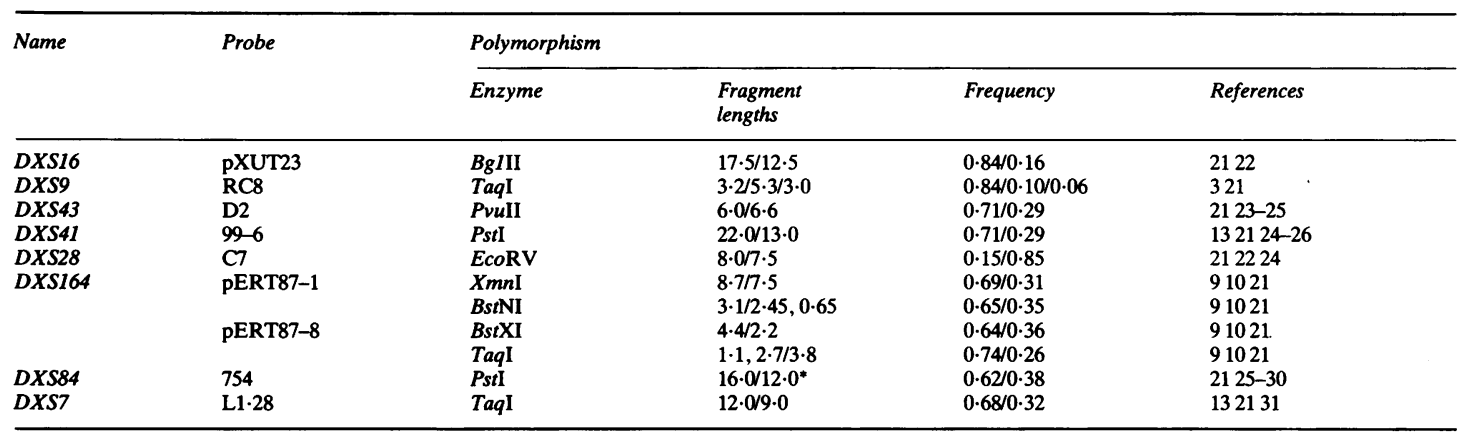

*Fragment lengths originally reported as 12.0 and $9.0 \mathrm{~kb}$, but estimated in our studies to be 16.0 and $12.0 \mathrm{~kb}$.

RC8, D2, 99-6, C7, pERT87-8 (two polymorphisms), pERT87-1 (two polymorphisms), 754, and L1.28. The probes used, the enzyme that reveals polymorphism in each case, the fragment lengths, the allele frequencies, and some linkage information about these markers have been described in Human Gene Mapping $8^{21}$ and other recent reports. ${ }^{22-31}$ For convenience, these data are summarised in table 1. Probes 754 and L1.28 hybridise with probes on the proximal side of the $X ; 21$ translocation, the other probes with sequences on its distal side, allowing $\mathrm{XJ} 1$ to be mapped between pERT87 and $754 .{ }^{10} 32$

\section{Results}

\section{ALLELE FREQUENCIES OF THE XJ MARKERS}

Table 2 shows the fragment lengths, allele frequencies, and heterozygote frequencies of the three polymorphic markers $\mathrm{XJ} 1 \cdot 1, \mathrm{XJ} 1 \cdot 2$, and $\mathrm{XJ} 2 \cdot 2$. For each of these polymorphisms, at least $40 \%$ of the women studied were heterozygous.

\section{LINKAGE DISEOUILIBRIUM WITHIN XJ}

The three markers $\mathrm{XJ} 1 \cdot 1, \mathrm{XJ} 1 \cdot 2$, and $\mathrm{XJ} 2 \cdot 2$ are in pronounced linkage disequilibrium with one another (table 3). Two haplotypes, one with the common allele at each locus, and the antithetical combination with the rare allele at each locus, account for $85 \%$ of

TABLE 2 XJ polymorphic markers.

\begin{tabular}{lrllll}
\hline Marker & $N o^{*}$ & \multicolumn{2}{l}{ Polymorphism } & \\
\cline { 3 - 6 } & & Enzyme & $\begin{array}{l}\text { Fragment } \\
\text { lengths }(k b)\end{array}$ & Frequencies & $\begin{array}{l}\text { Heterozygote } \\
\text { frequency } \\
\text { (theoretical) }\end{array}$ \\
\hline $\mathrm{XJ1} \cdot 1$ & 130 & TaqI & $3 \cdot 1 / 3 \cdot 8$ & $0 \cdot 72 / 0 \cdot 28$ & 0.40 \\
$\mathrm{XJ1} 12$ & 89 & BclI & $2 \cdot 0 / 1 \cdot 7$ & $0 \cdot 70 / 0 \cdot 30$ & 0.42 \\
$\mathrm{XJ} 2 \cdot 2$ & 95 & TaqI & $6 \cdot 4 / 7 \cdot 8$ & $0 \cdot 70 / 0 \cdot 30$ & 0.42 \\
\hline
\end{tabular}

*Number of independent $\mathrm{X}$ chromosomes typed for the marker.
TABLE $3 X J$ linkage disequilibrium: haplotype frequencies for 67 independent $X$ chromosomes.

\begin{tabular}{|c|c|c|c|c|c|c|}
\hline \multicolumn{3}{|c|}{ Haplotypes (fragment lengths) } & \multicolumn{4}{|c|}{ Frequency } \\
\hline \multirow[t]{2}{*}{$X J 1 \cdot 2$} & \multirow[t]{2}{*}{$X J 1 \cdot 1$} & \multirow[t]{2}{*}{$X J 2 \cdot 2$} & \multicolumn{2}{|c|}{ Observed } & \multicolumn{2}{|c|}{ Expected } \\
\hline & & & No & Proportion & No & Proportion \\
\hline $\begin{array}{l}2.0 \\
1.7\end{array}$ & $\begin{array}{l}3 \cdot 1 \\
3 \cdot 8\end{array}$ & $\begin{array}{l}6.4 \\
7.8\end{array}$ & $\begin{array}{l}43 \\
14\end{array}$ & $\begin{array}{l}0.64 \\
0.21\end{array}$ & $\begin{array}{r}24 \cdot 7 \\
1 \cdot 3\end{array}$ & $\begin{array}{l}0.37 \\
0 \cdot 02\end{array}$ \\
\hline $\begin{array}{l}2.0 \\
1.7\end{array}$ & $\begin{array}{l}3 \cdot 1 \\
3 \cdot 8\end{array}$ & $\begin{array}{l}7 \cdot 8 \\
6 \cdot 4\end{array}$ & $\begin{array}{l}2 \\
1\end{array}$ & $\begin{array}{l}0.03 \\
0.015\end{array}$ & $\begin{array}{r}10.7 \\
3.4\end{array}$ & $\begin{array}{l}0 \cdot 16 \\
0 \cdot 05\end{array}$ \\
\hline $\begin{array}{l}2.0 \\
1.7\end{array}$ & $\begin{array}{l}3 \cdot 8 \\
3 \cdot 1\end{array}$ & $\begin{array}{l}6.4 \\
7.8\end{array}$ & $\begin{array}{l}1 \\
2\end{array}$ & $\begin{array}{l}0.015 \\
0.03\end{array}$ & $\begin{array}{l}9 \cdot 4 \\
4 \cdot 0\end{array}$ & $\begin{array}{l}0.14 \\
0.06\end{array}$ \\
\hline $\begin{array}{l}2.0 \\
1.7\end{array}$ & $\begin{array}{l}3 \cdot 1 \\
3 \cdot 1\end{array}$ & $\begin{array}{l}7 \cdot 8 \\
6 \cdot 4\end{array}$ & $\begin{array}{l}2 \\
2\end{array}$ & $\begin{array}{l}0.03 \\
0.03\end{array}$ & $\begin{array}{l}4 \cdot 0 \\
9 \cdot 4\end{array}$ & $\begin{array}{l}0.06 \\
0.14\end{array}$ \\
\hline Total & & & 67 & $1 \cdot 00$ & 66.9 & 1.00 \\
\hline
\end{tabular}

$\chi^{2}=103, p<<0.001$.

Expected proportions are calculated on the basis of the total frequency of each allele in this sample.

the haplotypes observed, whereas they would account for only $39 \%$ if the alleles were in complete equilibrium. Further analysis of the markers in pairwise combinations indicates that the degree of disequilibrium is approximately the same between the pairs $\mathrm{XJ} 2 \cdot 2-\mathrm{XJ} 1 \cdot 1, \mathrm{XJ} 1 \cdot 1-\mathrm{XJ} 1 \cdot 2$, and $\mathrm{XJ} 2 \cdot 2-$ $\mathrm{XJ} 1 \cdot 2$ (data not shown).

The overall incidence of haplotype heterozygosity observed in our series $(54 \%)$ is higher than the 40 to $42 \%$ heterozygosity for the pair of alleles recognised by each individual probe; thus, full haplotypes are more useful for linkage analysis than individual markers alone.

RECOMBINATION FREQUENCIES FOR DMD, XJ, AND OTHER XP MARKERS

In view of the high prior probability of very close linkage between the markers studied, we are not presenting lod scores, but instead are reporting the recombination frequencies determined directly from 
the family data. If the linkage phase in an obligate heterozygote mother could not be determined directly from the pedigree, the most likely phase (that which explained the data with the least number of recombinations) has been inferred.

Table 4 summarises the number of informative meioses and the number of recombinations observed in pairwise combinations of DMD and the $\mathrm{XJ}$ haplotype with one another and each with probes RC8, D2, 99-6, C7, the pERT87-1/87-8 haplotype, 754, and L1-28. The cluster DMD-pERT87-XJ lies between $\mathrm{C} 7$ and 754 , but the arrangement of these three loci in relation to one another cannot be inferred from the recombination data alone, although physical mapping has shown that pERT87 is telomeric to XJ (fig 2). ${ }^{10} 32$

We have found two subjects recombinant for $\mathrm{DMD}$ and $\mathrm{XJ}$ in 45 informative meioses. The relevant pedigrees are presented in fig 3 . Pedigree 1 (HSC 14) shows a recombination within the $\mathrm{XJ}$ region itself, between the $\mathrm{XJ} 2 \cdot 2$ and $\mathrm{XJ} 1 \cdot 1$ polymorphic sites. This was the only such recombinant among 51 meioses informative for both $\mathrm{XJ} 2 \cdot 2$ and $\mathrm{XJ} 1 \cdot 1$. In this particular family, the mutation segregates with the $\mathrm{XJ} 2 \cdot 2$ marker and separates

TABLE 4 Recombination frequencies for $D M D$ and $X J$ with other DNA markers on Xp21.

\begin{tabular}{lllll}
\hline & \multicolumn{2}{l}{ DMD } & & \multicolumn{1}{l}{$X J$} \\
\cline { 2 - 4 } & $A^{*}$ & $B^{*}$ & Total & \\
\hline RC8 & $2 / 7$ & $0 / 1$ & $2 / 8$ & $1 / 5$ \\
D2 & $3 / 18$ & $1 / 3$ & $4 / 21$ & $2 / 10$ \\
$99-6$ & $1 / 13$ & $0 / 5$ & $1 / 18$ & $2 / 6$ \\
C7 & $0 / 19$ & $1 / 4$ & $1 / 23$ & $1 / 17$ \\
pERT87 & $4 / 52$ & $1 / 12$ & $5 / 64$ & $0 / 41$ \\
XJ & $2 / 39$ & $0 / 6$ & $2 / 45$ & - \\
754 & $7 / 43$ & $0 / 9$ & $7 / 52$ & $2 / 20$ \\
L1.28 & $7 / 24$ & $0 / 5$ & $7 / 29$ & $2 / 15$ \\
\hline
\end{tabular}

*For meioses involving DMD, offspring are classified as follows: $A$, normal or affected males, obligate heterozygotes; B, presumptive heterozygotes, females with raised serum creatine kinase activity who are first degree relatives of obligate heterozygotes or of affected males. from $\mathrm{XJ} 1 \cdot 1$ and $\mathrm{XJ} 1 \cdot 2$, as shown in the pedigree; thus the family's DMD mutation must be distal to $\mathrm{XJ} 1 \cdot 1$ on the chromosome. The recombination event, which occurred within a region only $9 \mathrm{~kb}$ in length, cannot be the cause of the mutation, since the mother is an obligate heterozygote. It suggests, however, that the $\mathrm{XJ}$ region may have a high recombination frequency in relation to its physical length. As discussed below, this idea is difficult to reconcile with the degree of linkage disequilibrium observed within the region.

Pedigree 2 (HSC 31) is a small phase unknown pedigree in which an obligate DMD heterozygote, who is also heterozygous for D2, pERT87, XJ, and 754 , has transmitted the same D2 and 754 alleles to both her affected sons (who are half-brothers), but has given them different pERT87 and XJ alleles. She is also heterozygous for a more remote distal marker, pXUT23, and again has given both sons the same allele. One interpretation is shown: two recombinations, one between D2 and pERT87 and the other between $\mathrm{XJ}$ and 754, in the meiosis giving rise to one son. Alternatively, the D2-pERT87 recombination could have occurred in the meiosis giving rise to one son and the $\mathrm{XJ}-754$ recombination in the meiosis leading to his half-brother. The position of the DMD mutation cannot be determined from this pedigree; although it is drawn in the figure between D2 and pERT87, it could equally well lie between pERT87 and XJ, or between XJ and 754 .

No pERT87-XJ recombinants were seen in 41 informative meioses. The lack of recombination in this region contrasts with the relatively high rate of recombination of DMD both with pERT87 (five recombinants in 64 informative meioses) and with $\mathrm{XJ}$ (two recombinants in 45 informative meioses).

\section{Discussion}

The XJ segment and the polymorphisms recognised within it will be useful in the continuing attempts, in many laboratories, to define the extent of the DMD

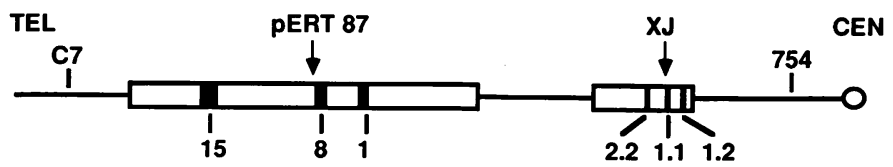

FIG 2 Schematic representation of the XJ/pERT87 region. Clones that detect polymorphism in the XJ region are designated $X J 1 \cdot 1,1 \cdot 2$, and $2 \cdot 2$. Clones that detect polymorphism in the pERT87 region are designated 87-1, 87-8, and 87-15. The relative positions of the random DNA markers 754 and $C 7$ are indicated, as are the positions of the centromere (CEN) and telomere (TEL). The total span of the $p E R T 87$ cloned region is $140 \mathrm{~kb},,^{33}{ }^{34}$ while the XJ region covers about $60 \mathrm{~kb}$ in a set of six overlapping clones. The two regions are non-overlapping based on comparison of restriction maps. 
locus and the nature of the mutations responsible for the disease. They also provide an additional system of markers for carrier detection and prenatal diagnosis. The three probes and $\mathrm{XJ} 2 \cdot 3$, which recognises the same polymorphism as $\mathrm{XJ} 2 \cdot 2$, are available on request for family studies.
Digestion with TaqI alone reveals both the $\mathrm{XJ} 1 \cdot 1$ and the $\mathrm{XJ} 2 \cdot 2$ markers, which are different enough in the fragment lengths of their alleles to be readable from the same gel. About $50 \%$ of the women in our sample are heterozygous for one or both of these two markers. Consequently it is convenient and may

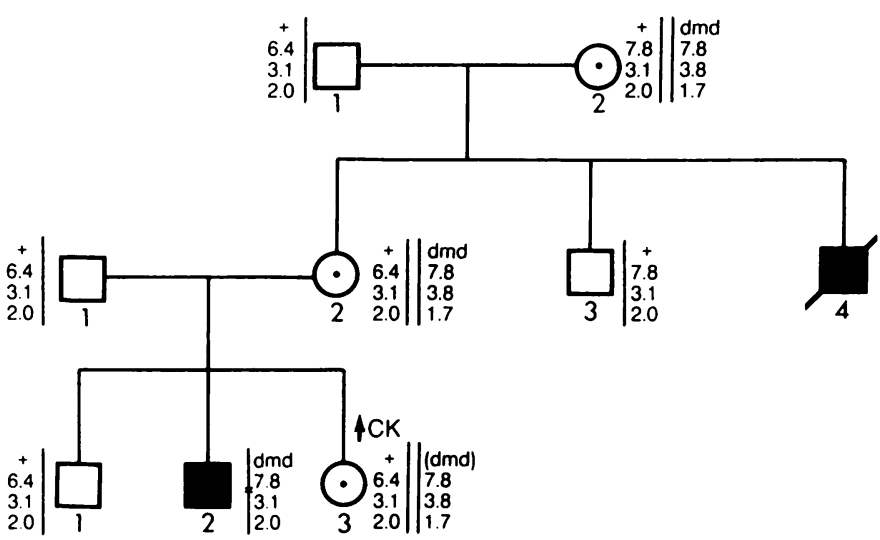

II

Pedigree 2

HSC 31

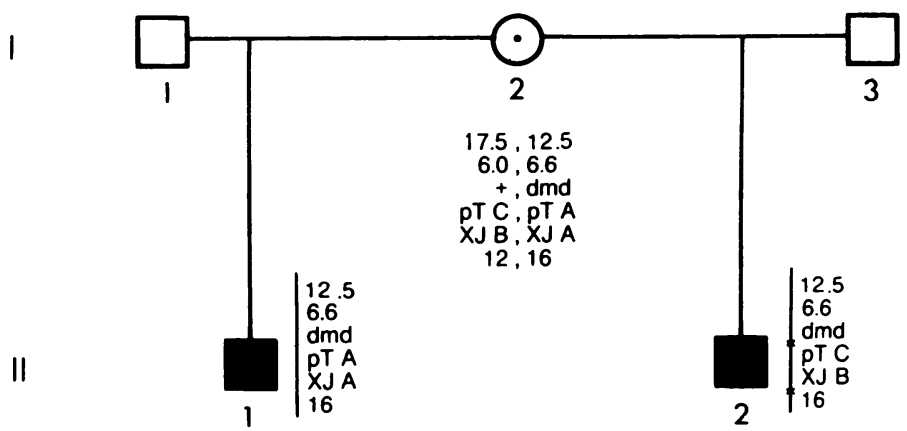

FIG 3 Pedigrees showing recombination between DMD and XJ. In pedigree 1, the recombination seen in III. 2 has occurred in meiosis in his mother II. 2 within the XJ segment, between the XJ2.2 and XJ1 1 polymorphic sites, and DMD segregates with the $X J 2 \cdot 2$ allele, indicating that the DMD mutation is distal to XJ in this family. Abbreviations:,+ dmd, alleles at DMD locus; $X \mathrm{~J} 2 \cdot 2$ alleles (fragment lengths, $\mathrm{kb}$ ) $6 \cdot 4,7 \cdot 8 ; \mathrm{XJ} 1 \cdot 1$ alleles $3 \cdot 1,3 \cdot 8 ; \mathrm{XJ} 1 \cdot 2$ alleles $2 \cdot 0,1 \cdot 7$. In pedigree 2, the linkage phase in the mother $I \cdot 1$ is unknown and there are alternative explanations of the pedigree (discussed in the text). Markers in sequence from distal to proximal: $p X U T 23, D 2, p E R T 87-8 / 87-1$ haplotype, XJ haplotype, 754. Though shown distal to the pERT87 markers, the precise location of the DMD mutation in this family cannot be determined. Further abbreviations, with enzyme used and fragment lengths $(k b)$ of alleles: $p T A, p E R T 87-8$ BstXI 4.4,

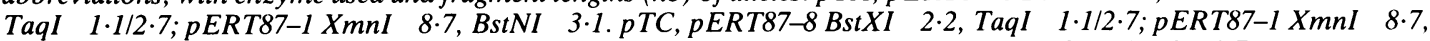

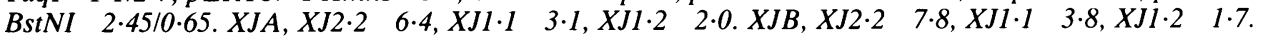


be sufficient to test possible heterozygotes for $\mathrm{XJ} 1 \cdot 2$ and $\mathrm{XJ} 2 \cdot 2$ alone. The additional chance of finding heterozygosity by subsequent testing for $\mathrm{XJ} 1 \cdot 2$ is only $4 \%$.

The region detected by the pERT87 probes is telomeric to the $\mathrm{XJ}$ segment, at an unknown distance from it. In the present study, no recombination was observed between pERT87 and XJ, whereas both pERT87 and XJ show 4 to $8 \%$ recombination with DMD. However, there is evidence from the analysis of deletions in DMD patients that pERT87 and XJ are separable, ${ }^{33}$ and chromosome walking from each one in the direction of the other has not yet revealed any overlap (unpublished observations). The tight linkage may simply be a reflection of their close physical proximity.

The strong linkage disequilibrium among the three $\mathrm{XJ}$ markers suggests that recombination is rare in this region, or alternatively that selection favours certain XJ combinations. Consequently, it is unexpected that in one of the two DMD-XJ recombinants we have observed, the recombination is actually within the $\mathrm{XJ}$ region, in the $9 \mathrm{~kb}$ stretch of DNA between the $\mathrm{XJ} 2 \cdot 2$ and $\mathrm{XJ} 1 \cdot 1$ polymorphic sites. The possibility that recombination is more frequent than expected in the DNA segment associated with DMD has been suggested, ${ }^{30}$ but one would not expect the pronounced linkage disequilibrium observed within the $\mathrm{XJ}$ region if recombination is frequent there. Further information from additional families may show whether the recombination we have observed is a unique event or a characteristic finding.

Pedigree 2 exemplifies the difficulty of accurate prenatal diagnosis without enough family information to indicate the linkage phase in the mother. The mother is heterozygous for each of six markers. An attempt at prenatal diagnosis in her second pregnancy would have revealed discrepancy between the information given by the flanking markers and that given by the pERT87 and XJ markers, and would have shown that in spite of the mother's numerous heterozygous markers, the DMD genotype of her fetus could not be accurately predicted.

We have used presumptive carriers as well as obligate carriers in analysis of our pedigrees and linkage data. We classify a woman as a 'presumptive carrier' on the basis of her high prior probability of being a carrier and serum CK activity raised above the upper limit of the normal range. For linkage analysis we select a value $20 \%$ or more above the $95 \%$ level of the normal range. CK assay has been the most frequently used and the most valuable of various tests applied to the identification of carriers. ${ }^{35}$ Most analyses of the distribution of CK in normal females and obligate carriers have concen- trated on the probability of misclassification of obligate carriers as normal rather than the misclassification of normal subjects as carriers. Carrier detection rates range from 50 to $80 \%$ in different studies, ${ }^{35} 36$ though one recent report found that only $45 \%$ of obligate carriers were identified when a $2.5 \%$ level of false positive results was assumed. ${ }^{37}$ For obligate carriers of BMD, the probability of raised $\mathrm{CK}$ has been estimated as $50 \% .{ }^{38}$ Though there is broad overlap in normal and carrier CK values, many obligate carriers have $\mathrm{CK}$ activity far above the levels seen in controls, ${ }^{39}$ and such grossly raised levels are accepted for genetic counselling as virtual confirmation of carrier status. ${ }^{40} \mathrm{CK}$ assay is an important adjunct to DNA marker studies, and can improve their interpretation. ${ }^{41} 42$ The probability of error in judgement of carrier status on the basis of a grossly raised CK level (much less than $1 \%$ ) is in some cases well below the probability that recombination of markers has occurred.

Though the fine structure of the DMD locus has not yet been fully characterised, the locus is already revealed as unexpectedly large and complex. ${ }^{34}$ The DNA cloned from the $\mathrm{XJ}$ region, now extended to about $70 \mathrm{~kb}$ by chromosome walking, provides a substantial new addition to the growing list of DNA probes available for the analysis of the Xp21 linked muscular dystrophies and other disease genes within or near Xp21. The XJ polymorphic markers, originating in a DNA segment thought to be within or very close to the DMD structural gene or a regulatory sequence, were expected to exhibit tight linkage with DMD or even to be within the gene itself. Similarly, the pERT87 clone, which contains $137 \mathrm{~kb}$ of DNA absent from the DNA of a male diagnosed as having DMD and three other $\mathrm{X}$ linked disorders (chronic granulomatous disease, retinitis pigmentosa, and the McLeod red cell phenotype), and which can detect DNA deletions in other DMD patients, is believed to lie within the DMD locus, or at least to be very close to it. Its polymorphic markers, like those of $\mathrm{XJ}$, were expected to show close or absolute linkage to DMD. However, the frequency of recombination of DMD with both the $\mathrm{XJ}$ and pERT markers, combined with our imperfect knowledge of the extent of heterogeneity among mutations responsible for DMD, now suggest that the $\mathrm{XJ}$ and $\mathrm{pERT} 87$ polymorphisms must be used with caution for clinical purposes, especially for prenatal diagnosis.

Perhaps the most important problem in the molecular genetics of DMD is the site of the DMD mutation(s) relative to the markers C7, pERT87, $\mathrm{XJ}$, and 754. All recombinants for DMD-pERT87 or DMD-XJ require analysis for flanking markers, to determine on which side of pERT87 and XJ the 
mutations map. Unfortunately, in pedigree 2, the linkage phase in the mother 1.1 is unknown, and there is a double recombination (or one in each of two affected sons) between D2 and 754. The DMD mutation could be segregating with either of these markers, making the site of the mutation uncertain.

Indeed, the challenge that lies ahead is to learn how the pERT87 and XJ regions can lie close enough to the DMD gene to detect small deletions and reciprocal translocations that cause the disease, yet be sufficiently distant to be separated from the DMD mutation in 4 to $8 \%$ of meioses. Clearly, until transcribed sequences in the form of cDNA clones are available, it will not be possible to determine whether the DMD locus is a single gene of very large size, a set of interdependent genes, or a gene located in a segment of DNA with unusual recombinational properties.

\section{Note added in proof}

The DNA segment $\mathrm{XJ}$ has now been assigned the name DXS206.

We acknowledge with thanks the cooperation of Dr E Gordon Murphy, Director of the Muscular Dystrophy Clinic, The Hospital for Sick Children, and the many patients and families who provided blood samples for this study. Probes of X chromosome origin were kindly provided by Drs K Davies, L Kunkel, J-L Mandel, P Pearson, G van Ommen, and $\mathrm{H}$ Willard. The work was supported by grants from the Medical Research Council of Canada (to RGW, PNR, and MWT), the Muscular Dystrophy Association of Canada (to RGW, PNR, and MWT), and the Muscular Dystrophy Association of America (RGW).

\section{References}

${ }^{1}$ McKusick VA. The human gene map 1 December 1984. Clin Genet 1985;27:207-39.

2 Goodfellow PN, Davies KE, Ropers HH. Report of the committee on the genetic constitution of the $\mathrm{X}$ and $\mathrm{Y}$ chromosomes. Human Gene Mapping 8, 1985. Cytogenet Cell Genet 1985;40:296-352.

${ }^{3}$ Murray JM, Davies KE, Harper PS, Meredith L, Mueller CR, Williamson $R$. Linkage relationship of a cloned DNA sequence on the short arm of the $\mathrm{X}$ chromosome to Duchenne muscular dystrophy. Nature 1982;300:69-71.

4 Verellen-Dumoulin C, Freund M, DeMeyer R, et al. Expression of an X-linked muscular dystrophy in a female due to translocation involving Xp21 and non-random inactivation of the normal X chromosome. Hum Genet 1984;67:115-9.

5 Lindenbaum RH, Clarke G, Patel C, Moncrieff M, Hughes JT. Muscular dystrophy in an X;1 translocation female suggests that Duchenne locus is on X chromosome short arm. J Med Genet 1979;16:389-92.

6 Jacobs PA, Hunt PA, Mayer M, Bart RD. Duchenne muscular dystrophy (DMD) in a female with an $\mathrm{X} /$ autosome translocation: further evidence that the DMD locus is at Xp21. Am J Hum Genet 1981;33:513-8.
${ }^{7}$ Francke V, Ochs HD, de Martinville B, et al. Minor Xp21 chromosome deletion in a male associated with expression of Duchenne muscular dystrophy, chronic granulomatous disease, retinitis pigmentosa, and McLeod syndrome. Am J Hum Genet 1985;37:250-67.

${ }^{8}$ Ingle C, Williamson $\mathrm{R}$, de la Chapelle $\mathrm{A}$, et al. Mapping DNA sequences in a human $\mathrm{X}$-chromosome deletion which extends across the region of the Duchenne muscular dystrophy mutation. Am J Hum Genet 1985;37:451-62.

9 Kunkel LM, Monaco AP, Middlesworth W, Ochs HD, Latt SA. Specific cloning of DNA fragments absent from the DNA of a male patient with an $\mathrm{X}$ chromosome deletion. Proc Natl Acad Sci USA 1985;82:4778-82.

${ }^{10}$ Monaco AP, Bertelson CJ, Middlesworth W, et al. Detection of deletions spanning the Duchenne muscular dystrophy locus using a tightly linked DNA segment. Nature 1985;316:842-5.

11 Kingston HM, Sarfarazi M, Thomas NS, Harper PS. Localisation of the Becker muscular dystrophy gene on the short arm of the $\mathrm{X}$ chromosome by linkage to cloned DNA sequences. Hum Genet 1984;67:6-17.

12 Brown CS, Thomas NS, Sarfarazi M, et al. Genetic linkage relationships of seven DNA probes with Duchenne and Becker muscular dystrophy. Hum Genet 1985;71:62-74.

${ }^{13}$ Fadda S, Mochi M, Roncuzzi L, et al. Definitive localization of Becker muscular dystrophy in Xp by linkage to a cluster of DNA polymorphisms (DXS43 and DXS9). Hum Genet 1985;71:33-6.

14 Boyd Y, Buckle VJ. Cytogenetic heterogeneity of translocations associated with Duchenne muscular dystrophy. Clin Gene 1986;29:108-15.

15 Worton RG, Duff C, Sylvester JE, Schmickel RD, Willard HF. Duchenne muscular dystrophy involving translocation of the dmd gene next to ribosomal RNA genes. Science 1984;224:1447-9.

16 Ray PN, Belfall B, Duff C, et al. Cloning of the breakpoint of af $\mathrm{X} ; 21$ translocation associated with Duchenne muscular dystro phy. Nature 1985;318:672-5.

17 Loenen WAM, Blattner FR. Lambda Charon vectors (Ch 32 33,34 and 35) adapted for cloning in recombination-deficient hosts. Gene 1983;26:171-9.

18 Maniatis T, Fritsch EF, Sambrook J. Molecular cloning: a laboratory manual. Cold Spring Harbor: Cold Spring Harbor Laboratory, 1982.

19 Yanisch-Perron C, Vieira J, Messing J. Improved M13 phage cloning vectors and host strains: nucleotide sequences of the M13mp18 and pUC19 vectors. Gene 1985;33:103-19.

${ }^{20}$ Melton DA, Drieg PA, Rebagliati MR, Maniatis T, Zinn K, Green MR. Efficient in vitro synthesis of biologically active RNA and RNA hybridization probes from plasmids containing a bacteriophage SP6 promoter. Nucleic Acids Res 1984;12:703556.

${ }^{21}$ Willard HF, Skolnick MH, Pearson PL, Mandel JL. Report of the committee on human gene mapping by recombinant DNA techniques. Human Gene Mapping 8, 1985. Cytogenet Cell Genet 1985;40:360-489.

22 Bakker E, Hofker MH, Goor N, et al. Prenatal diagnosis and carrier detection of Duchenne muscular dystrophy with closely linked RFLPs. Lancet 1985;i:655-8.

23 Aldridge J, Kunkel L, Bruns G, et al. A strategy to reveal highfrequency RFLPs along the human X chromosome. Am J Hum Genet 1984;36:546-64.

24 De Martinville B, Kunkel LM, Bruns G, et al. Localization of DNA sequences in region Xp21 of the human $\mathrm{X}$ chromosome; search for molecular markers close to the Duchenne muscular dystrophy locus. Am J Hum Genet 1985;37:235-49.

25 Wilcox DE, Affara NA, Yates JRW, Ferguson-Smith MA, Pearson PL. Multipoint linkage analysis of the short arm of the $\mathrm{O}$ human $\mathrm{X}$ chromosome in families with $\mathrm{X}$-linked muscular dystrophy. Hum Genet 1985;70:365-75.

${ }^{26}$ Drayna D, White $R$. The genetic linkage map of the human $X$ chromosome. Science 1985;230:753-8. 
${ }^{27}$ Dorkins H, Junien C, Mandel JL, et al. Segregation analysis of a marker localised Xp21.2-Xp21.3 in Duchenne and Becker muscular dystrophy families. Hum Genet 1985;71:103-7.

${ }^{28}$ Hofker M, Wagenaar M, Goor N, Bakker B, van Ommen G, Pearson PL. Isolation of probes detecting RFLPs from $\mathrm{X}$ chromosome specific libraries; potential use for diagnosis of Duchenne muscular dystrophy. Hum Genet 1985;70:148-56.

${ }^{29}$ Brown CS, Pearson PL. Thomas NS, Sarfarazi M, Harper PS, Shaw DJ. Linkage analysis of a DNA polymorphism proximal to the Duchenne and Becker muscular dystrophy loci on the short arm of the X chromosome. J Med Genet 1985;22:179-81.

30) Davies KE, Speer A, Hermann F, et al. Human X chromosome markers and Duchenne muscular dystrophy. Nucleic Acids Res 1985:13:3419-26.

${ }^{31}$ Davies KE, Pearson PL, Harper PS, et al. Linkage analysis of two cloned sequences flanking the Duchenne muscular dystrophy locus on the short arm of the human X chromosome. Nucleic Acids Res 1983;11:2302-12.

32 Kean VM, MacLeod HL, Thompson MW, Ray PN, VerellenDumoulin C, Worton RG. Paternal inheritance of translocation chromosomes in a $t(X ; 21)$ patient with $X$ linked muscular dystrophy. J Med Genet 1986;23:491-3.

33 Thomas NST, Ray PN. Worton RG, Harper PS. Molecular deletion analysis in Duchenne muscular dystrophy. J Med Genet 1986;23:509-15.

${ }^{34}$ Kunkel LM, Hejtmancik JF, Caskey CT, et al. Analysis of deletions in DNA from patients with Becker and Duchenne muscular dystrophy. Nature 1986;322:73-7.

35 Harper PS. Carrier detection in Duchenne muscular dystrophy: a critical assessment. In: Schotland DL, ed. Disorders of the motor unit. New York: John Wiley, 1982:821-46.
${ }^{36}$ Sibert JR, Harper PS, Thompson RJ, Newcombe RG. Carrier detection in Duchenne muscular dystrophy. Evidence from a study of obligatory carriers and mothers of isolated cases. Arch Dis Child 1979;54:534-7.

${ }^{37}$ Griggs RC, Mendell JR, Brooke MH, et al. Clinical investigation in Duchenne dystrophy. V. Use of creatine kinase and pyruvate kinase in carrier detection. Muscle Nerve 1985;8:60-7.

${ }^{38}$ Skinner R, Emery AEH, Anderson AJB, Foxall C. The detection of carriers of benign (Becker-type) X-linked muscular dystrophy. J Med Genet 1975;12:131-4.

${ }^{39}$ Percy ME, Andrews DF, Thompson MW. Duchenne muscular dystrophy using logistic discrimination: serum creatine kinase, hemopexin, pyruvate kinase and lactate dehydrogenase in combination. Am J Med Genet 1982;13:27-38.

40 Harper PS. Practical genetic counselling. 2nd ed. Bristol: Wright, 1984

${ }^{41}$ Harper PS, O'Brien T, Murray JM, Davies KE, Pearson P, Williamson $R$. The use of linked DNA polymorphisms for genotype prediction in families with Duchenne muscular dystrophy. J Med Genet 1983;20:252-4.

42 Pembrey ME, Davies KE, Winter RM, et al. The clinical use of DNA markers linked to the gene for Duchenne muscular dystrophy. Arch Dis Child 1983;59:208-16.

Correspondence and requests for reprints to $\mathrm{Dr}$ Margaret W Thompson, Department of Genetics, Hospital for Sick Children, Toronto, Ontario M5G $1 \mathrm{X} 8$, Canada. 